\title{
Laparoscopic and endoscopic cooperative surgery for intra-mucosal gastric carcinoma adjacent to the ulcer scars
}

\author{
Masahiko Aoki ${ }^{1,2^{*}}$ D, Satoshi Tokioka ${ }^{1,2}$, Ken Narabayashi ${ }^{1,2}$, Akitoshi Hakoda ${ }^{1,2}$, Yosuke Inoue ${ }^{1,2}$, Naoki Yorifuji ${ }^{1,2}$, \\ Yoshihide Chino ${ }^{3}$, Isao Sato ${ }^{3}$, Yutaro Egashira ${ }^{4}$, Toshihisa Takeuchi ${ }^{2}$ and Kazuhide Higuchi ${ }^{2}$
}

\begin{abstract}
Background: Laparoscopic and endoscopic cooperative surgery (LECS) was performed for the local resection of gastrointestinal stromal tumors (GIST). LECS enables less resection of the lesion area and preserves function. Furthermore, LECS can be safely performed and independent of tumor location. However, LECS is not usually used for cases involving gastric carcinoma because it may seed tumor cells into the peritoneal cavity when the gastric wall is perforated. Here, we report seven cases of LECS for intra-mucosal gastric carcinoma, which were difficult to carry out by endoscopic submucosal dissection (ESD) because of ulcer scars.

Methods: We performed LECS (classical LECS and inverted LECS) in seven cases of intra-mucosal gastric carcinoma. All cases had ulcer scars beside the tumor. LECS was chosen because ESD was thought to be difficult because of the ulcer scars. We only selected cases in which the patients did not prefer gastrectomy and endoscopic examination was indicative of intra-mucosal gastric carcinoma.

Results: In all cases, LECS was performed without severe complications including postoperative stenosis. Histopathology findings proved that the tumors were intra-mucosal carcinoma and had been resected completely. Furthermore, there were ulcer scars (UI IIIs-IVs) beside the tumor. Currently, dissemination and recurrence have not been apparent.

Conclusions: LECS for intra-mucosal gastric carcinoma is an efficient procedure, but strict observation is necessary because of the possibility of peritoneal dissemination. Results suggest that LECS is likely to be effective for cases involving intra-mucosal gastric carcinoma that are difficult to treat by ESD due to ulcer scars.
\end{abstract}

Keywords: Laparoscopic and endoscopic cooperative surgery (LECS), Gastric carcinoma, Ulcer scar, Endoscopic submucosal dissection (ESD)

\section{Background}

Laparoscopic and endoscopic cooperative surgery (LECS) is routinely performed for the local resection of gastrointestinal stromal tumors (GIST) [1-4]. This procedure has been on the national insurance list since February 2014 in Japan. LECS is an endoscopic dissection of the mucosal to submucosal layers followed by laparoscopic seromuscular resection and is independent of tumor location. Incision lines are determined, and a mucosal to submucosal incision

\footnotetext{
* Correspondence: aokidayo110@gmail.com

'Internal Medicine of Gastroenterology, First Towakai Hospital, Takatsuki, Osaka 569-0081, Japan

2Internal Medicine (II), Osaka Medical College, Takatsuki, Osaka 569-8686, Japan

Full list of author information is available at the end of the article
}

is performed endoscopically, while the seromuscular layer is incised and the incision line is laparoscopically closed.

However, LECS is not usually used in cases involving gastric carcinoma because it may seed tumor cells into the peritoneal cavity if the gastric wall is perforated.

In general, endoscopic submucosal dissection (ESD) is applied for early gastric cancer [5, 6]. Endoscopic resection is less invasive than conventional surgery [7]. In our cases, we performed LECS for early gastric carcinoma because ulcer scars were located close by; consequently, ESD was likely to be very difficult to perform, leading to an expectation of a more complicated procedure and a broader range of dissection owing to the scarring. Furthermore, reports have shown that the larger the 
lesion, the higher the incidence of bleeding and perforation [8]. Also, while stricture is known to occur after ESD $[9,10]$, LECS results in no postoperative transformation of the remaining stomach [1]. We choose LECS to prevent these complications, and only selected cases involving patients who did not prefer gastrectomy and in which endoscopic examination was indicative of intramucosal gastric carcinoma. We performed LECS after fully explaining the procedure to the patients and with the permission of the local ethics committee. In the beginning, we performed classical LECS in four cases. Peritoneal dissemination has not yet been reported in these cases. However, to prevent the seeding of tumor cells into the peritoneal cavity when the gastric wall was perforated, we have performed inverted LECS [11] since February 2016.

\section{Methods}

We retrospectively assessed seven cases at the First Towakai Hospital. Patients were 66- to 91-year-old male. We choose the cases where endoscopic examination was indicative of intra-mucosal gastric carcinoma adjacent to the ulcer scars, so ESD was thought to be difficult. Also, the patients preferred to avoid a gastrectomy. All procedures followed were in accordance with the ethical standards of the responsible committee on human experimentation (institutional and national), with the Declaration of Helsinki of 1964 and later versions, and also with the permission of the First Towakai Hospital IRB/ethics committee. Informed consent or a substitute for it was obtained from all patients for their being included in the study. Consent, for the publication of the case reports and any additional related information, was taken from the patients involved in the study. From January 2014 to February 2017, we performed classical LECS in four cases and inverted LECS in three cases of intra-mucosal gastric carcinoma. The surgical procedure first involved processing the serosal side laparoscopically around the tumor. We then used endoscopy to determine the incision line and entire circumference of the mucosal incision using an IT-2 knife. We used a needle knife to perforate the gastric wall and then used the IT-2 knife to make a full-thickness incision. After the incision using the IT-2 knife, we inserted an ultrasonically activated device into the perforation hole and accomplished the incision. A specimen was taken out from the mouth side or naval incision. The incision line was then closed using a laparoscopic hand-suturing technique. When a specimen was taken from the ventral side, we quickly recovered it and placed it into a specimen bag as soon as possible.

In the case of inverted LECS, after determining the incision line endoscopically, the gastric wall was lifted up circumferentially outside the incision line by several stitches resembling a crown (Fig. 1). This procedure made the tumor turn towards the intra-gastric cavity when the gastric wall was perforated.

\section{Results}

Mean patient age for the classical and inverted LECS cases was $78.8 \pm 9.3$ years and $79.0 \pm 3.6$ years, respectively. Mean operation time was $181.5 \pm 37.9 \mathrm{~min}$ and $192.3 \pm 51.9 \mathrm{~min}$, for the two types of surgery, with a mean blood loss of $11.3 \pm 5.4 \mathrm{ml}$ and $11.0 \pm 6.5 \mathrm{ml}$, for classical and inverted LECS, respectively. Mean length of postoperative hospital stay was $16.3 \pm 2.1$ days and $17 \pm$ 5.1 days, respectively (Table 1 ). In all cases, there were no postoperative complications including stenosis. At the time of writing, dissemination and recurrence have not been recognized during follow-up (Table 2). Histopathology findings proved that tumors were intramucosal carcinomas and had been resected completely. Furthermore, there were ulcer scars (Ul IIIs-IVs) beside the tumors. In here, we listed one representative case of each LECS procedure.
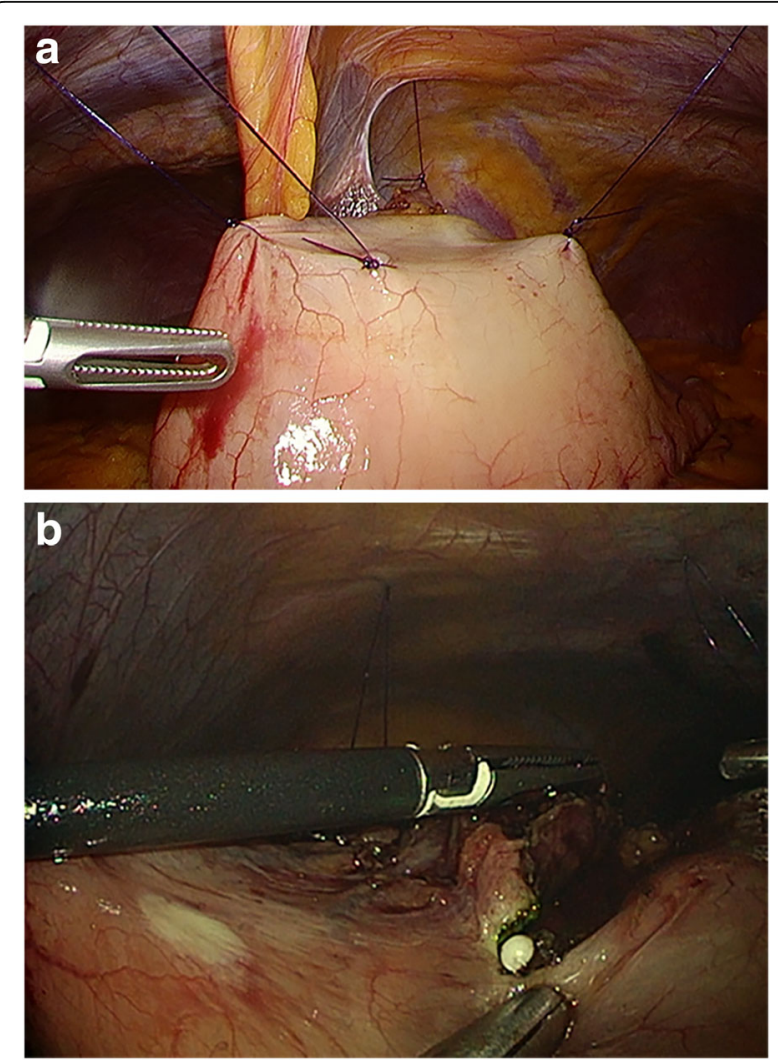

Fig. 1 a The gastric wall was lifted up circumferentially outside of the incision line by several stitches. $\mathbf{b}$ The tip of the IT-2 knife was inserted into the perforation and a full-thickness incision was carried out under laparoscopy 
Table 1 Characteristics and operative data for cases involving laparoscopic and endoscopic cooperative surgery (LECS)

\begin{tabular}{|c|c|c|c|}
\hline & & Classical $(n=4)$ & Inverted $(n=3)$ \\
\hline Sex (male/female) & & $4 / 0$ & $3 / 0$ \\
\hline Age (years) & & $78.8 \pm 9.3$ & $79.0 \pm 3.6$ \\
\hline \multicolumn{4}{|l|}{ Location of tumor } \\
\hline & Angle, lesser curvature & 2 & 2 \\
\hline & Body, posterior & 1 & \\
\hline & Body, lesser curvature & 1 & \\
\hline & Body, greater curvature & & 1 \\
\hline Tumor size (mm) & & $14.5 \pm 3.6(10-20)$ & $11.7 \pm 6.2(5-20$ \\
\hline Operation time (min) & & $181.5 \pm 37.9$ & $192.3 \pm 51.9$ \\
\hline Intraoperative blood loss (ml) & & $11.3 \pm 5.4$ & $11.0 \pm 6.5$ \\
\hline Conversion to open surgery & & 0 & 0 \\
\hline Postoperative complications & & 0 & 0 \\
\hline Gastric fullness & & 0 & 0 \\
\hline Anastomotic leakage & & 0 & 0 \\
\hline Anastomotic stenosis & & 0 & 0 \\
\hline Anastomotic bleeding & & 0 & 0 \\
\hline Postoperative hospital stay (days) & & $16.3 \pm 2.1$ & $17.0 \pm 5.1$ \\
\hline
\end{tabular}

Case 1 is a 91-year-old male. Tumor size was $20 \mathrm{~mm}$ and located at the angle of the lesser curvature. Ulcer scar was on the anal side of the tumor. Classical LECS was performed without complication. Histopathology findings proved that the tumor was intra-mucosal carcinoma and was resected completely. Ulcer scars (Ul IIIs-IVs) were evident beside the tumor (Fig. 2).

Case 2 is an 82-year-old male. Tumor size was $20 \mathrm{~mm}$ and located at the angle of the lesser curvature. Ulcer scar was located on the posterior side of the tumor. Inverted LECS was performed without complication. Histopathology findings proved that the tumor was intra-mucosal carcinoma and was resected completely. Ulcer scars (Ul IIIs-IVs) were evident beside the tumor.

\section{Discussion}

Intra-mucosal gastric cancer carries a low risk of lymph node metastasis [12]. ESD is indicated as a standard treatment (absolute indication or expanded indication) [13]. In our cases, the tumors were predicted as intramucosal gastric carcinomas, as a result of endoscopic

Table 2 Follow-up and passage after laparoscopic and endoscopic cooperative surgery (LECS)

\begin{tabular}{|c|c|c|c|c|c|c|}
\hline Case & Age (years) & Sex & $\begin{array}{l}\text { Tumor size } \\
(\mathrm{mm})\end{array}$ & Classical/inverted & Follow-up after LECS (image) & Passage after LECS \\
\hline 1 & 91 & Male & 20 & Classical & $\begin{array}{l}\text { Endoscopy; } 3,9,20 \text { months } \\
\text { CT; } 3 \text { months }\end{array}$ & $\begin{array}{l}\text { No dissemination and recurrence, } 42 \text { months } \\
\text { after LECS (alive) }\end{array}$ \\
\hline 2 & 66 & Male & 10 & Classical & $\begin{array}{l}\text { Endoscopy; } 6,18,20 \text { months } \\
\mathrm{CT} ; 16 \text { months }\end{array}$ & $\begin{array}{l}\text { No dissemination and recurrence, } 35 \text { months } \\
\text { after LECS (alive) }\end{array}$ \\
\hline 3 & 75 & Male & 13 & Classical & $\begin{array}{l}\text { Endoscopy; } 3 \text { months } C T ; 1 \text {, } \\
21 \text { months }\end{array}$ & $\begin{array}{l}\text { No dissemination and recurrence, died of } \\
\text { pneumonia } 24 \text { months after LECS }\end{array}$ \\
\hline 4 & 83 & Male & 15 & Classical & $\begin{array}{l}\text { Endoscopy; } 15,27 \text { months } \\
\mathrm{CT} ; \\
11,17,23,29 \\
\text { months }\end{array}$ & $\begin{array}{l}\text { No dissemination and recurrence, } 33 \text { months } \\
\text { after LECS (alive) }\end{array}$ \\
\hline 5 & 82 & Male & 20 & Inverted & $\begin{array}{l}\text { Endoscopy; } 3,6,11 \text { months } \\
\mathrm{CT} ; 7,12 \text { months }\end{array}$ & $\begin{array}{l}\text { No dissemination and recurrence, } 18 \text { months } \\
\text { after LECS (alive) }\end{array}$ \\
\hline 6 & 74 & Male & 10 & Inverted & $\begin{array}{l}\text { Endoscopy; } 3 \text { months } \\
\mathrm{CT} ; 2,4,7 \text { months }\end{array}$ & $\begin{array}{l}\text { No dissemination and recurrence, } 14 \text { months } \\
\text { after LECS (alive) }\end{array}$ \\
\hline 7 & 81 & Male & 5 & Inverted & Endoscopy; 3 months & $\begin{array}{l}\text { No dissemination and recurrence, } 6 \text { months } \\
\text { after LECS (alive) }\end{array}$ \\
\hline
\end{tabular}



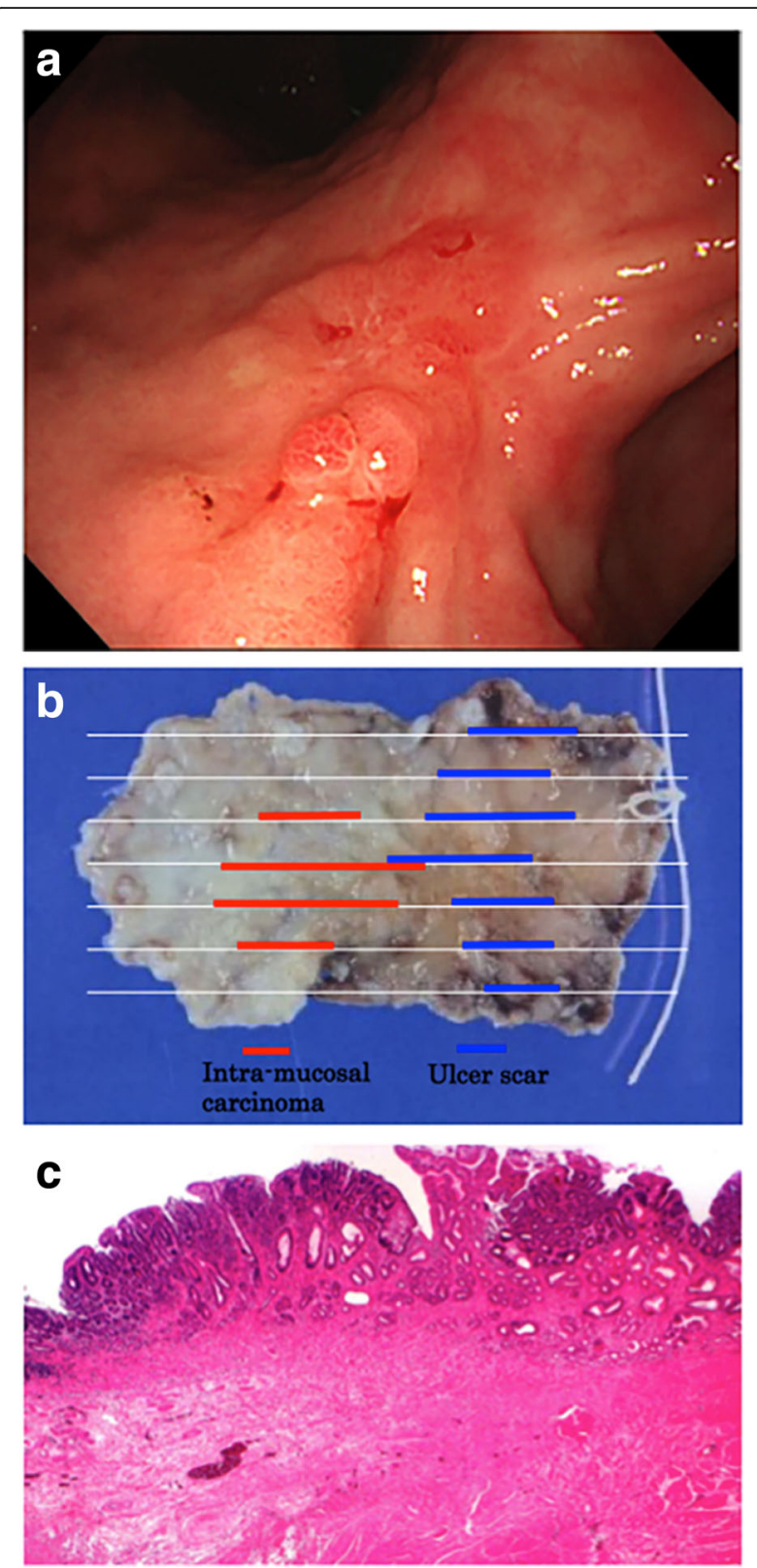

Fig. 2 Endoscopic image (a) showing an intra-mucosal carcinoma of an ulcer scar, along with a pathological specimen (b) and histopathological image (c) of case 1

examination. However, it was expected that the procedure would be complicated if ESD was performed. The greater the degree of submucosal fibrosis, the longer an ESD procedure can last and the higher the frequency of complications such as perforation and immediate bleeding [14]. In order to carry out the dissection safely with an accurately cut line, and to avoid excessive resection of the gastric wall, we choose to use LECS for our cases. LECS was successfully applied in cases of intra-mucosal gastric carcinomas which would have been difficult to treat with ESD due to ulcer scars. In all cases, there was no postoperative stricture, which may occur if ESD was performed. In a previous study, LECS was also performed for lateral-spreading mucosal gastric cancer which would have been difficult to treat with ESD because of the high incidence of complications and the long surgical time required for ESD [11].

Previous reports have shown that gastric perforation during endoscopic resection for gastric carcinoma does not lead to peritoneal dissemination, even in the long term [15]. However, we need to try not to seed tumor cells into the peritoneal cavity to prevent peritoneal dissemination when the gastric wall is perforated during the LECS procedure. Thus, in the inverted LECS procedure, the gastric wall is lifted up circumferentially outside of the incision line by several stitches [11]. This procedure enables us to prevent contact between the tumor and visceral tissue and prevents gastric juice from falling into the peritoneal cavity. Other techniques such as "CLEAN-NET" or "NEWS" [16-18] also prevent peritoneal dissemination by allowing non-exposure gastric wall resection. However, the mucosal layer shifts significantly from the seromuscular layer during surgery, so that they are not applied for tumor located at the EGJ or pyloric ring, and also the muscle layer and seromuscular layer may be incorrectly dissected. On the other hand, LECS can be applied for any tumor location [19]. Thus, LECS is likely to be effective in these cases, although strict observation is necessary for LECS in cases of intramucosal gastric carcinoma.

Due to ulcer scars located in the vicinity of a tumor, sometimes it is difficult to diagnose whether the tumor represents intra-mucosal carcinoma or submucosal infiltration carcinoma. On the other hand, sentinel node mapping for early gastric cancer has been reported $[20,21]$; detection rate and the accuracy of prediction of lymph node metastasis based on sentinel status are of high value. In the future, combining sentinel node mapping technology and the adoption of LECS for early gastric carcinoma will be very important in dealing with cases involving intra-mucosal carcinoma that would be difficult to treat by ESD due to ulcer scars or location, and in cases of submucosal carcinoma without lymph node metastasis.

\section{Conclusion}

LECS for the stomach is an efficient, safe procedure that can preserve function. LECS for intra-mucosal gastric carcinoma is an efficient procedure, but strict observation is necessary because of the possibility of peritoneal dissemination. Results suggest that LECS is likely to be effective for cases involving intra-mucosal gastric carcinoma that are difficult to treat by ESD due to ulcer scars. 


\section{Acknowledgements}

Not applicable

\section{Funding}

None

Availability of data and materials

Not applicable

\section{Authors' contributions}

MA performed the research, analyzed the data, and wrote the manuscript. ST and TT edited the manuscript. All authors approved the final manuscript.

\section{Ethics approval and consent to participate}

The study was approved by the ethics committee of the First Towakai Hospital.

\section{Consent for publication}

The study was undertaken with patient's consent.

\section{Competing interests}

The authors declare that they have no competing interests.

\section{Publisher's Note}

Springer Nature remains neutral with regard to jurisdictional claims in published maps and institutional affiliations.

\section{Author details}

Internal Medicine of Gastroenterology, First Towakai Hospital, Takatsuki, Osaka 569-0081, Japan. ${ }^{2}$ Internal Medicine (II), Osaka Medical College, Takatsuki, Osaka 569-8686, Japan. ${ }^{3}$ Endoscopic Surgery Center, First Towakai Hospital, Takatsuki, Osaka 569-0081, Japan. ${ }^{4}$ Department of Pathology, Osaka Medical College, Takatsuki, Osaka 569-8686, Japan.

\section{Received: 1 November 2017 Accepted: 6 March 2018}

Published online: 12 March 2018

\section{References}

1. Hiki N, Yamamoto Y, Fukunaga T, Yamaguchi T, Nunobe S, Tokunaga M, Miki A, Ohyama S, Seto S. Laparoscopic and endoscopic cooperative surgery for gastrointestinal stromal tumor dissection. Surg Endosc. 2008;22:1729-35.

2. Choi SM, Kim MC, Jung GJ, Kim HH, Kwon HC, Choi SR, Jang JS, Jeong JS. Laparoscopic wedge resection for gastric GIST: long-term follow-up results. Eur J Surg Oncol. 2007;33:444-7.

3. Kawahira H, Hayashi H, Natsume T, Akai T, Uesato M, Horibe D, Mori M, Hanari N, Aoyama H, Nabeya Y, Shuto K, Matsubara H. Surgical advantages of gastric SMTs by laparoscopy and endoscopy cooperative surgery. Hepato-Gastroenterology. 2012;59:415-7.

4. Hoteya S, Haruta S, Shinohara H, Yamada A, Furuhata T, Yamashita S, Kikuchi D, Mitani T, Ogawa O, Matsui A, lizuka T, Udagawa H, Kaise M. Feasibility and safety of laparoscopic and endoscopic cooperative surgery for gastric submucosal tumors, including esophagogastric junction tumors. Dig Endosc. 2014:26:538-44.

5. Gotoda T. A large endoscopic resection by endoscopic submucosal dissection procedure for early gastric cancer. Clin Gastroenterol Hepatol. 2005;3:S71-3.

6. Fujishiro M, Yahagi N, Nakamura M, Kakushima N, Kodashima S, Ono S, Kobayashi K, Hashimoto T, Yamamichi N, Tateishi A, Shimizu Y, Oka M, Ogura K, Kawabe T, Ichinose M, Omata M. Successful outcomes of a novel endoscopic treatment for GI tumors: endoscopic submucosal dissection with a mixture of high-molecular-weight hyaluronic acid, glycerin, and sugar. Gastrointest Endosc. 2006;63:243-9.

7. Ono H, Kondo H, Gotoda T, Shirao K, Yamaguchi H, Saito D, Hosokawa K, Shimoda T, Yoshida S. Endoscopic mucosal resection for treatment of early gastric cancer. Gut. 2001;48:225-9.

8. Oda I, Gotoda T, Hamanaka H, Equchi T, Saito Y, Matsuda T, Bhandari P, Emura F, Saito D, Ono H. Endoscopic submucosal dissection for early gastric cancer: technical feasibility, operation time and complications from a large consecutive series. Dig Endosc. 2005;17:54-8.
9. lizuka H, Kakizaki S, Sohara N, Onozato Y, Ishihara H, Okamura S, Itoh H, Mor M. Stricture after endoscopic submucosal dissection for early gastric cancers and adenomas. Dig Endosc. 2010;22:282-8.

10. Ohara Y, Toyonaga T, Tanabe A, Takihara H, Baba S, Inoue T, Ono W, Kawara F, Tanaka S, Azuma T. Endoscopic antralplasty for severe gastric stasis after wide endoscopic submucosal dissection in the antrum. Clin J Gastroenterol. 2016;9:63-7.

11. Nunobe S, Hiki N, Gotoda T, Murao T, Haruma K, Matsumoto H, Hirai T, Tanimura S, Sano T, Yamaguchi T. Successful application of laparoscopic and endoscopic cooperative surgery (LECS) for a lateral-spreading mucosal gastric cancer. Gastric Cancer. 2012;15:338-42.

12. Yamao $T$, Shirao K, Ono H, Kondo H, Saito D, Yamaguchi H, Sasako M, Sano T, Ochiai A, Yoshida S. Risk factors for lymph node metastasis from intramucosal gastric carcinoma. Cancer. 1996;77:602-6.

13. Japanese Gastric Cancer Association. Japanese gastric cancer treatment guidelines 2014 (ver. 4). Gastric Cancer. 2017;20:1-19.

14. Jeong JY, Oh YH, Yu YH, Park HS, Lee HL, Eun CS, Han DS. Does submucosal fibrosis affect the results of endoscopic submucosal dissection of early gastric tumors? Gastrointest Endosc. 2012;76(1):59-66.

15. Ikehara H, Gotoda T, Ono H, Oda I, Saito D. Gastric perforation during endoscopic resection for gastric carcinoma and the risk of peritoneal dissemination. Br J Surg. 2007:94:992-5.

16. Inoue H, Ikeda H, Hosoya T, Yoshida A, Onimaru M, Suzuki M, Kudo S. Endoscopic mucosal resection, endoscopic submucosal dissection, and beyond: full-layer resection for gastric cancer with nonexposure technique (CLEAN-NET). Surg Oncol Clin N Am. 2012;21:129-40.

17. Goto O, Mitsui T, Fujishiro M, Wada I, Shimizu N, Seto Y, Koike K. New method of endoscopic full-thickness resection: a pilot study of non-exposed endoscopic wall-inversion surgery in an ex vivo porcine model. Gastric Cancer. 2011;14:183-7.

18. Mitsui T, Goto O, Shimizu N, Hatao F, Wada I, Niimi K, Asada I, Fujishiro M, Koike K, Seto Y. Novel technique for full-thickness resection of gastric malignancy: feasibility of nonexposed endoscopic wall-inversion surgery (news) in porcine models. Surg Laparosc Endosc Percutan Tech. 2013;23: e217-21.

19. Hiki N, Nunobe S, Matsuda T, Hirasawa T, Yamamoto Y, Yamaguchi T. Laparoscopic and endoscopic cooperative surgery. Dig Endosc. 2015;27(2): 197-204.

20. Takeuchi $H$, Kitagawa $Y$. New sentinel node mapping technologies for early gastric cancer. Ann Surg Oncol. 2013;20:522-32.

21. Kitagawa Y, Takeuchi H, Takagi Y, Natsugoe S, Terashima M, Murakami N, Fujimura T, Tsujimoto $\mathrm{H}$, Hayashi $\mathrm{H}$, Yoshimizu N, Takagane A, Mohri $Y$, Nabeshima K, Uenosono Y, Kinami S, Sakamoto J, Morita S, Aikou T, Miwa K, Kitajima M. Sentinel node mapping for gastric cancer: a prospective multicenter trial in Japan. J Clin Oncol. 2013;31(29):3704-10.

\section{Submit your next manuscript to BioMed Central} and we will help you at every step:

- We accept pre-submission inquiries

- Our selector tool helps you to find the most relevant journal

- We provide round the clock customer support

- Convenient online submission

- Thorough peer review

- Inclusion in PubMed and all major indexing services

- Maximum visibility for your research

Submit your manuscript at www.biomedcentral.com/submit
Biomed Central 